\title{
Influence of Environmental Conditions on Infection of Peach Shoots by Taphrina deformans
}

\author{
V. Rossi, M. Bolognesi, L. Languasco, and S. Giosuè
}

Institute of Entomology and Plant Pathology, "S. Cuore" Catholic University, Via E. Parmense 8429100 Piacenza, Italy. Accepted for publication 3 October 2005.

\begin{abstract}
Rossi, V., Bolognesi, M., Languasco, L., and Giosuè, S. 2006. Influence of environmental conditions on infection of peach shoots by Taphrina deformans. Phytopathology 96:155-163.

The effect of weather conditions on the infection of peach shoots by Taphrina deformans was investigated both under orchard conditions and in controlled-environment experiments. Leaf curl incidence and severity were related to rainfall, length of wet periods, and temperature during wetness and during the incubation period, as well as to the development stage of shoots. Surface wetness was more important than rainfall for infection to occur. Minimum rainfall for infection was $3 \mathrm{~mm}$, with a wet

period of at least $12.5 \mathrm{~h}$; higher amounts of rainfall did not cause infection when the wet period they triggered was shorter. Wet periods initiated by dew or fog were too short for infection to occur. Infection occurred only when air temperature was $<16^{\circ} \mathrm{C}$ during the wet period and $<19^{\circ} \mathrm{C}$ during incubation. Logistic equations relating relative disease incidence and either duration of wetness or temperature were developed under controlled-environment conditions, with asymptotes at $\geq 48 \mathrm{~h}$ of wetness and $\leq 8^{\circ} \mathrm{C}$ for temperature, respectively. Rate of shoot and leaf development during the season influenced disease development, so that three different periods of susceptibility were defined, maximum susceptibility being between bud break and petal fall due to a low development rate of shoots.
\end{abstract}

Peach leaf curl, caused by Taphrina deformans (Berk.) Tul., has been reported worldwide on peach and nectarine, but its economic impact differs by production area (19). In northern Italy, leaf curl is a serious disease (21): it occurs every year and causes epidemics that frequently affect 60 to $90 \%$ of the shoots. In early spring, young developing leaves show yellow to reddish areas which progressively thicken and pucker, causing the leaf to curl. Infected leaves abscise prematurely or remain attached, gradually drying and turning dark brown. Infection also can extend to the green shoots which appear thickened and distorted. Infection on fruit is usually less severe; however, in some cases, 30 to $50 \%$ of fruit show irregular, wrinkled reddish lesions.

Differences in disease occurrence are related to meteorological factors, which play a key role in the infection process. Reports from different peach-growing areas show that leaf curl disease occurs only when repeated rainfall coincides with low temperature during early bud development $(1,2,10,13,17,24)$.

Safran and Levy (22) incorporated information about the role of rainfall and temperature into a model estimating probability for leaf curl infection under Israeli conditions. This model takes into account the maximum air temperature during rain events occurring between bud break and 6 weeks after bud break. The effect of temperature is described by an optimum curve in the interval between 5 and $39^{\circ} \mathrm{C}$, with maximum infection probability at $24^{\circ} \mathrm{C}$. The effect of rain is considered for days with at least $10 \mathrm{~mm}$ of rain using a Poisson distribution, with maximum infection probability for rainfall $>25 \mathrm{~mm}$ per day. Giosuè et al. (11) validated the Israeli model in the Po valley (northern Italy), and modified minimum conditions of both temperature and rainfall for infection. The modified model was accurate in determining leaf curl infection but was not able to estimate its severity. To improve model performance, an experiment was initiated in 1999, aimed at

Corresponding author: V. Rossi; E-mail address: vittorio.rossi@unicatt.it

DOI: 10.1094/PHYTO-96-0155

(C) 2006 The American Phytopathological Society better defining the relationships among rainfall, temperature, and disease severity (unpublished data). Groups of shoots on peach trees which had been affected severely by leaf curl in the previous season were covered with plastic bags, and each group was exposed to a single rain event, between bud break and mid-May 1999. Disease symptoms appeared early (1 April) in the shoots that did not receive rainfall, being always protected by the plastic cover. Dew frequently formed under the plastic cover, and a prolonged wetness of host surfaces occurred in early March. Thus, it was supposed that surface wetness allowed infection to occur also in the absence of rainfall, and that inoculum was present on the infection sites at the beginning of the season.

This hypothesis was in contrast to the essential role of rainfall observed by Mix (15) and Safran and Levi (22) under orchard conditions, and with findings of Mundy (18) and Cook and Baker (6), who never found disease symptoms on plants cropped in greenhouses or under covers, with the exception of shoots growing outside the cover.

To better define the role of weather conditions in the infection process of $T$. deformans, further experiments were performed for a 3-year period (2000 to 2002) in a peach orchard severely affected by leaf curl, by relating disease occurrence to rainfall, length of wet periods, and temperature during wetness and during the incubation period. To complement orchard observations, experiments were carried out in controlled-environment conditions, and quantitative relationships among infection, duration of wetness, and temperature regimes during both wetness and incubation were derived.

\section{MATERIALS AND METHODS}

Experiments in controlled-environment conditions. Between spring and winter 2000, 2-year-old potted peach plants 'Early Maycrest' were placed under peach trees in a 'Julia' orchard, located in Zattaglia (Ravenna), a peach-growing area in the hills of the southern Po valley ( $\approx 300 \mathrm{~m}$ above sea level). During this period, the orchard was severely affected by leaf curl, with abundant production of ascospores on the infected leaves serving as natural 
inoculum. The same was repeated in 2001 and 2002. During winter, plants were removed and placed under a cover. At bud break (shoot tip $2 \mathrm{~mm}$ in length), plants were placed in a mist chamber at $100 \%$ relative humidity and maintained wetted through a fine misting of water, taking care that plants did not drip water. At the end of the wetting period, plants were exposed to a gentle air current generated by a fan that dried leaves within $15 \mathrm{~min}$; afterward, plants were placed in growth chambers for incubation. Three environmental conditions were maintained: duration of wetness, temperature during the wet period, and temperature during incubation. To study the effect of wetness, plants were kept in the mist chamber for $6,12,18,24,48$, or $60 \mathrm{~h}$ at $12^{\circ} \mathrm{C}$, and then incubated at $12^{\circ} \mathrm{C}$ without misting. To study the effect of temperature during wetness, plants were wetted for $48 \mathrm{~h}$ using different temperature regimes between 5 and $23^{\circ} \mathrm{C}$ (tested temperatures changed over the three experiments, with $5^{\circ} \mathrm{C}$ being the reference temperature included in all experiments) and then incubated at $12^{\circ} \mathrm{C}$. To study the effect of temperature during incubation, plants were wetted for $48 \mathrm{~h}$ at $11^{\circ} \mathrm{C}$ and then incubated at different temperatures between 8 and $24^{\circ} \mathrm{C}$ (tested temperatures changed over experiments, with $12^{\circ} \mathrm{C}$ being the reference temperature included in all experiments). Each combination of environmental conditions was applied to three potted plants; the experiments were performed three times on the plants that had been exposed in the orchard in 2000, 2001, and 2002.

In another experiment, six groups of potted plants which had been exposed in the orchard and kept under cover were placed in a growth chamber $\left(15^{\circ} \mathrm{C}\right)$ for different time intervals to manipulate shoot development, so that plants had shoots of different lengths when they were transferred to the mist chamber. The growth stage of each group of plants was expressed as the number of visible leaves and length of the leaf tuft (before shoot elongation) of the shoot. Plants were kept wet for $48 \mathrm{~h}$ at $11^{\circ} \mathrm{C}$, and then incubated at $12.5^{\circ} \mathrm{C}$. Three potted plants were considered for each shoot development stage; this experiment was performed once on plants exposed in the orchard in 2001.

All plants were inspected daily in order to determine the time of disease appearance. Afterward, incidence of infected shoots was calculated as a percentage of the total number of growing shoots (30 shoots per plant on average).

Controlled-environment data analysis. A preliminary analysis of variance was performed on disease data (incidence of infected shoots transformed as arcsine $\sqrt{\%}$ ) collected in the experiments. Because neither year nor plant replicate influenced disease incidence significantly, data were aggregated over years and plants. To point out the quantitative relationships between environmental factors and disease incidence, the percentages of shoots affected in each wet period or temperature regime were transformed to relative disease incidence expressed on a 0 -to-1 scale, where 1 is the maximum incidence observed at optimum wetness or temperature.

Linear and nonlinear regression analysis then was used to fit experimental data: relative disease incidence, or numbers of days of incubation, were regressed against length of the wet period, temperature during wetness, or temperature during incubation. Goodness of fit was evaluated using the standard error of parameters and the distribution of actual data versus the estimated data points. Coefficient of determination $\left(R^{2}\right)$ was calculated for linear regression and adjusted $R^{2}$ for nonlinear regression (5). For nonlinear models, the number of iterations taken by the Marquardt algorithm to converge on parameter estimates and residual mean square also were evaluated (20). All statistical analyses were performed using SPSS (version 11.5; SPSS Inc., Chicago).

Experiments with potted plants in the orchard. Between May 1999 and January 2000, 2-year-old potted peach plants of 'Rome Star' were exposed to natural inoculum in the orchard of Zattaglia as previously described. At the end of the exposure period and until bud break, plants were removed from the orchard and placed under a cover, far from any additional source of inoculum. Starting from bud break, groups of three plants were placed in the orchard again and remained there until the end of the first rain event; afterward, pots were placed under the cover again. The first group of plants was exposed on 1 March and the last on 11 May; 12 groups were exposed in aggregate. Plants were observed in order to determine the time of symptom appearance and disease incidence as a percentage of infected shoots over the total number of developing shoots ( 20 developing shoots per plant on average). Hourly meteorological data of temperature, relative humidity, rain, and leaf wetness duration were recorded by a thermo-wetness-hygrograph and a rainfall recorder (model UM 7200/E and UM 8100, respectively; SIAP, Bologna, Italy) placed near the potted plants. The leaf wetness sensor measures the conductivity value (in MOhm) of a stratified fiberglass surface to which two electrodes have been applied; it produces an on/off output, where wet $<1$ MOhm and dry $>1$ MOhm.

Disease assessments. Between 2000 and 2002, observations were made in the same 'Julia' peach orchard in Zattaglia. Trees were 14 years old in 2000. They were palmate trained, spaced $4.6 \mathrm{~m}$ between rows and $3 \mathrm{~m}$ between plants, cropped following the usual practice, but not sprayed with fungicides. Meteorological data were recorded using the previously cited recorders placed inside the orchard; significant meteorological events, like the presence of snow, dew, or fog, were recorded based on visual observations.

In 2000, 150 shoots were randomly tagged within the canopy of ten trees and inspected two to three times per week. In 2001, there were 340 tagged shoots, and they were inspected every 2 to 3 days; in 2002, 602 shoots were observed at 1- to 2-day intervals. On each inspection, data on host growth were collected as (i) proportion of breaking buds, (ii) shoot development stage (leaf tuft or shoot length and number of leaves), and (iii) and growth stages using the $\mathrm{BBCH}$ scale (3). Data on disease progress also were collected on each leaf of the tagged shoots; for this purpose, leaves were numbered based on their position along the shoot, position 1 being the first basal leaf. To assess disease severity on leaves, a simple scale was developed, based on the proportion of the leaf blade occupied by symptoms $(3,15,30,50,70$, and $100 \%)$. Leaf necrosis, premature leaf abscission, and infection on the shoot axis also were recorded.

Orchard data analysis. Disease data were analyzed in such a way as to characterize each infection event and to separate infection events from each other. Each infection was characterized based on the proportion of shoots affected by leaf curl symptoms, position of the first leaf infected, and number and severity of the diseased leaves.

Using meteorological data collected in the orchard, all days with wet periods of at least $30 \mathrm{~min}$ triggered by either rainfall, dew, or fog were identified. Duration of each wet period was calculated, assuming that interruptions of wetness $<4 \mathrm{~h}$ were not influential; for instance, a period with $6 \mathrm{~h}$ of wetness, $2 \mathrm{~h}$ of dryness, and $12 \mathrm{~h}$ of additional wetness was considered as an 18-h wet period. Average temperature during the wet period (Tinf) then was calculated. As a first step, it was considered that each wet period had caused infection. Average temperature during incubation (Tinc) then was calculated over the time interval between the beginning of the wet period and the day when the incubation period should have ended, according to the results obtained in the controlled-environment conditions of the previously described experiments. When disease symptoms actually appeared, the corresponding wet period was considered as a true infection period. All the wet periods were split into two groups: (i) periods with infection and (ii) periods without infection. Distribution of data within each group then was analyzed by calculating summary statistics (average, standard deviation, minimum, and maximum) and by drawing box and whiskers plots; statistical differences between the two groups were tested by the $t$ test for means and by the 
Kolmogorov-Smirnov test for distributions under the null hypothesis of equality of the two data sets.

Based on these analyses, minimal conditions for infection to occur were identified separately for rainfall, wet period duration, Tinf, and Tinc. These minimal conditions then were applied together with the data collected between 2000 and 2002 and actual versus estimated successful infections were tested using the $\chi^{2}$ test.

\section{RESULTS}

Infection in controlled-environment conditions. In the experiments aimed at studying the effect of wetness, disease symptoms were observed on $\approx 850$ shoots in aggregate, distributed homogeneously in the seven periods of wetness duration. Control plants were not subjected to wetness and they did not show disease symptoms. Plants wetted for $6 \mathrm{~h}$ showed the disease occasionally ( 1 infected shoot over 165 growing shoots considered in aggregate, with two infected leaves). Incidence of infected shoots was 2 and $3 \%$ in plants wetted for 12 and $18 \mathrm{~h}$, respectively, with 2 and 1.3 curled leaves per affected shoot, respectively. Plants kept wet for $24 \mathrm{~h}$ showed $11.4 \%$ of growing shoots infected, each with 2.7 leaves with symptoms. Finally, when plants were wetted for 48 or $60 \mathrm{~h}, 43 \%$ of shoots were infected, but the number of diseased leaves per shoot did not increase, being 2.6 on average. Therefore, the proportion of infected shoots and leaves increased with increasing wetness duration, whereas the number of diseased leaves per infected shoot did not change. The data for infected shoots were well described by a logistic equation (Fig. 1).

To study the effect of temperature during the wetness period, $\approx 800$ shoots were observed on plants kept wet for $48 \mathrm{~h}$ at different air temperatures. Because the tested temperature regimes changed over experiments, data were expressed as a proportion of infected shoots obtained at $5^{\circ} \mathrm{C}$, the reference temperature included in all experiments, which always showed the highest disease incidence: on average, $45 \%$ of shoots were infected at $5^{\circ} \mathrm{C}$, each of them with 2.5 leaves showing symptoms. In the plants kept wet at $9^{\circ} \mathrm{C}$, leaf curl incidence remained very high, being $95 \%$ of the inci-

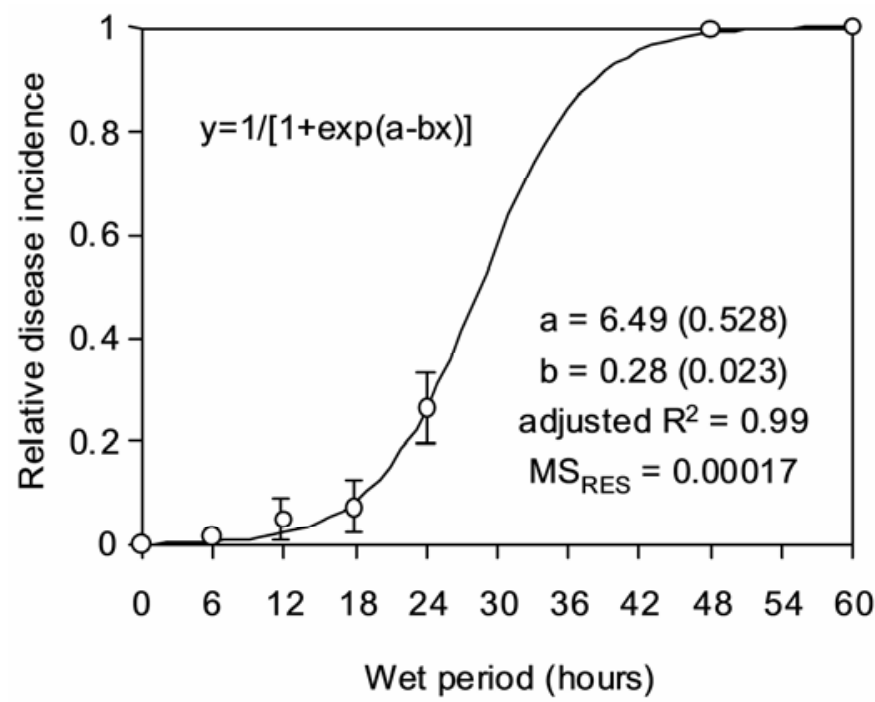

Fig. 1. Relationship between relative leaf curl incidence and duration of the wet period in potted peach plants kept in a mist chamber under favorable conditions of temperature $\left(12^{\circ} \mathrm{C}\right)$. Points are the means of different experiments and plants, whereas bars indicate the $95 \%$ confidence intervals for the means ( $n=6$ to 9 ). Relative incidence was obtained by setting the maximum incidence of infected shoots $(43 \%)$ to 1 . Line shows the fit of the nonlinear logistic model to experimental data: $a$ and $b$ are the estimated equation parameters, with their approximate standard errors; adjusted $R^{2}$ is calculated as by Clewer and Scarisbrick (5); $\mathrm{MS}_{\mathrm{RES}}$ is the residual mean square. dence found at $5^{\circ} \mathrm{C}$, with 3 infected leaves per shoot. At $11^{\circ} \mathrm{C}$, the disease appeared on only $52 \%$ of the shoots infected at the reference temperature, and they had only 1.3 infected leaves on average. When temperature ranged between 15 and $23^{\circ} \mathrm{C}$, the disease did not appear (at 16,21 , and $23^{\circ} \mathrm{C}$ ) or it affected only one leaf (at $15,17.5$, and $19^{\circ} \mathrm{C}$ ). Therefore, the proportion of infected shoots decreased with increasing temperature during the wet period. The number of leaves infected per diseased shoot also decreased with increasing temperature, being 2.5 or 3 at lower temperatures and 1 at the higher ones. Dynamics of infected shoots over temperature was fitted by a logistic equation (Fig. 2).

Incubation temperature did not affect disease incidence between 8 and $15^{\circ} \mathrm{C}$, but it reduced disease incidence $\approx 10$-fold in the interval 16 to $19^{\circ} \mathrm{C}$ and did not allow disease to appear at $20^{\circ} \mathrm{C}$ or higher incubation regimes (data not shown). Length of incubation was reduced linearly as temperature increased (Fig. 3).

To verify the effect of shoot length on infection, 330 shoots were observed on plants kept wet for $48 \mathrm{~h}$ at $11^{\circ} \mathrm{C}$ and incubated at $12.5^{\circ} \mathrm{C}$ at different times after bud break. When the leaf tuft was shorter than or equal to $2.5 \mathrm{~cm}$ (i.e., all leaves were unfolded), disease symptoms appeared on 16 to $18 \%$ of shoots, on 1.3 leaves per shoot (Table 1). Disease did not appear on shoots wetted in any later growth stage.

Disease development in 2000. Twelve groups of potted plants previously exposed to natural $T$. deformans inoculum were exposed to single rain events between 1 March and 11 May (Table 2 ). An average of $\approx 60$ developing shoots were observed for each group of plants, with the exception of groups I and V, which had only 14 and 18 shoots, respectively. Group I was exposed in the early season, when few buds had broken, whereas plants of group $\mathrm{V}$ accidentally had a low proportion of developing shoots over total ones.

Rainfall ranged between 2 and $19 \mathrm{~mm}$ per exposure period, whereas duration of continuous wetness triggered by rainfall was between 4 and $59 \mathrm{~h}$. Leaf wetness periods $>24 \mathrm{~h}$ always were interrupted once or twice, for 1.5 to $4 \mathrm{~h}$; only for groups VII and XII was the total duration of wetness interruption longer, 6.5 and $6 \mathrm{~h}$, respectively, over two shorter interruptions. Tinf was between 5.7 and $19.5^{\circ} \mathrm{C}$, whereas Tinc was 10.6 to $20.2^{\circ} \mathrm{C}$.

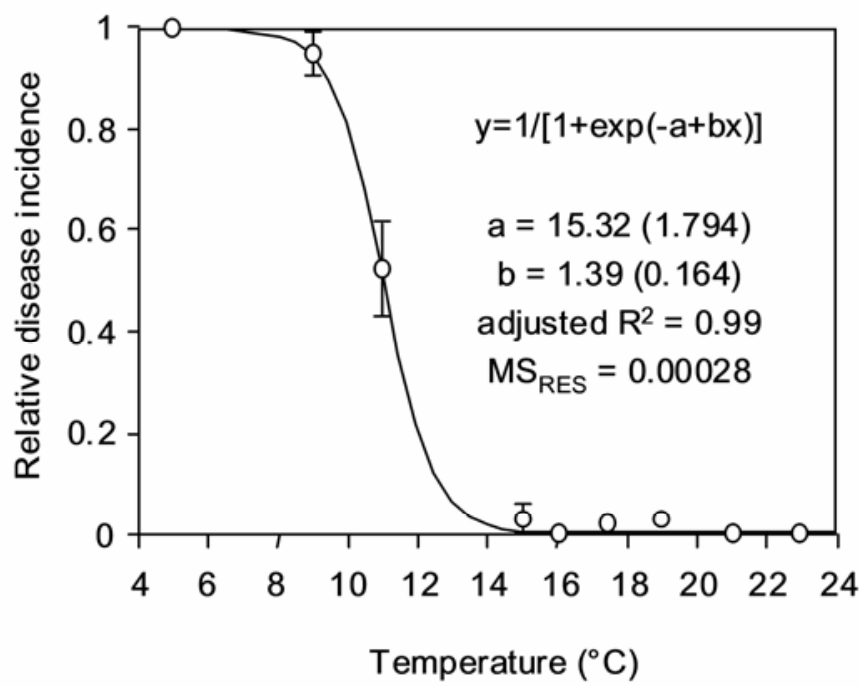

Fig. 2. Relationship between relative leaf curl incidence and temperature during the wet period in potted peach plants kept in a mist chamber for $48 \mathrm{~h}$. Points are the means of different experiments and plants, while bars indicate the $95 \%$ confidence intervals for the means $(n=6$ to 9$)$. Relative incidence was obtained by setting the maximum incidence of infected shoots (45\%) to 1 . Line shows the fit of the non-linear logistic model to experimental data: a and $\mathrm{b}$ are the estimated equation parameters, with their approximate standard errors; adjusted $R^{2}$ is calculated as by Clewer and Scarisbrick (5); $\mathrm{MS}_{\mathrm{RES}}$ is the residual mean square. 
Symptoms appeared on plants exposed on 3 to 4 (group VII), 9 to 11 (group IX), and 29 to 30 April (group X). These groups showed 48,51 , and $14 \%$ of infected shoots, respectively, with 1.8 to 3.1 infected leaves per infected shoot (Table 2). These three groups of plants received 13 to $19 \mathrm{~mm}$ of rainfall, with duration of wetness between 35 and $59 \mathrm{~h}$; Tinf was maximum of $15^{\circ} \mathrm{C}$, whereas Tinc was $<19^{\circ} \mathrm{C}$. On 19 and 26 April, new symptoms also were observed in the orchard trees. The former affected $60 \%$ of the shoots, which showed two to four infected leaves beginning

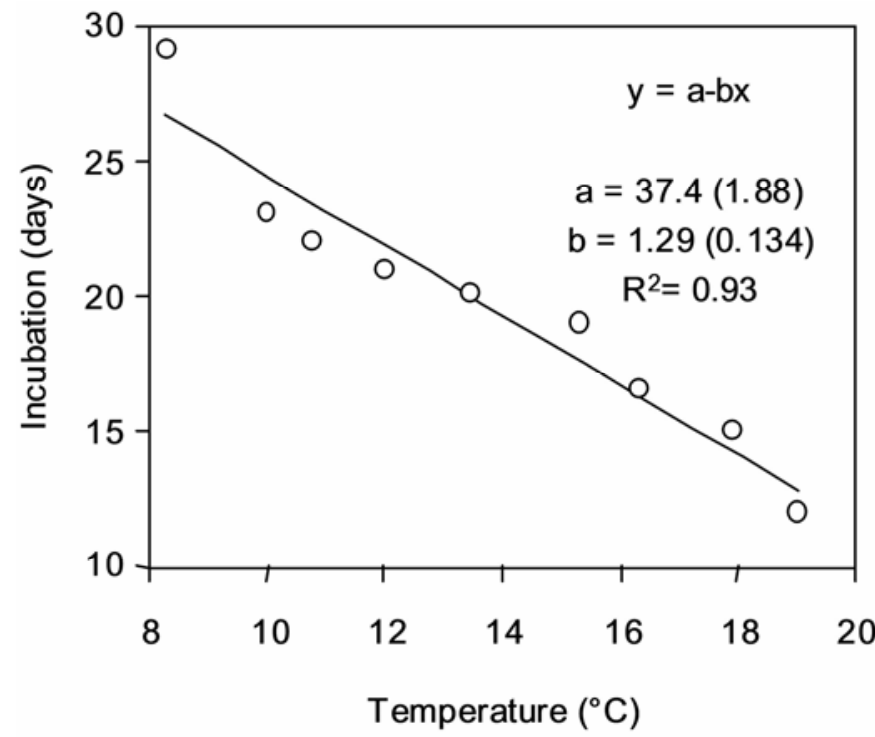

Fig. 3. Relationship between the incubation period following infection of peach shoots by Taphrina deformans and temperature during incubation in potted peach plants kept in a mist chamber for $48 \mathrm{~h}$ under favorable conditions for infection $\left(11^{\circ} \mathrm{C}\right)$. Line shows the fit of the linear model to experimental data: $\mathrm{a}$ and $\mathrm{b}$ are the estimated equation parameters, with their standard errors. from leaf position 7 to 9; the latter infection appeared on $35 \%$ of the shoots, with one infected leaf in position 10 or 11 . The infection period observed on potted plants of group X did not produce new visible symptoms in the orchard trees.

No symptoms appeared on the other potted plants. Group I was exposed when only a few buds had broken. They received $4 \mathrm{~mm}$ of rainfall, with $16 \mathrm{~h}$ of wetness at $7.4^{\circ} \mathrm{C}$ and Tinc of $10.6^{\circ} \mathrm{C}$. These conditions enabled infection in the orchard trees; starting from 25 March, $\approx 1 \%$ of the shoots showed severe disease symptoms on the first five to seven leaves. Similarly, potted plants of group $\mathrm{V}$, which were exposed to $13 \mathrm{~mm}$ of rainfall with $24 \mathrm{~h}$ of wetness at $9.7^{\circ} \mathrm{C}$ on 28 to 29 March, did not show leaf curl symptoms on the limited number of developing shoots. In contrast, disease appeared on the orchard trees; from 12 April, two to three leaves were affected on $30 \%$ of the shoots, starting from position 4 to 6 .

Groups II, III, IV, and VIII were exposed to wet periods shorter than those that produced infection on either potted plants or orchard trees. Groups XI and XII had long wetness durations (43 and $27 \mathrm{~h}$, respectively), but they were exposed to higher temperatures during both the wet period $\left(17.7\right.$ and $19.5^{\circ} \mathrm{C}$, respectively) and the incubation period (19.7 and $20.2^{\circ} \mathrm{C}$, respectively).

Disease development in 2001. In 2001, bud break started in mid-February and ended on 9 March $(100 \%$ of buds at stage 09 $\mathrm{BBCH}$ ). Stage 59 (most flowers with petals forming a hollow sphere) occurred on 11 to 13 March, stage 65 (full flowering) around 19 March, and stage 69 (end of flowering, all petals fallen) at the end of March (Fig. 4A). Shoots developed slowly until the end of March, when only four to six leaves per shoot were still present; afterward, shoots grew rapidly at a rate of one leaf every 3.5 days (Fig. 4A). Following the beginning of bud break, the first rainfall occurred on 24 February; afterward, precipitation was distributed regularly over time until the end of May (Fig. 4A).

First leaf curl symptoms appeared between 19 and 27 March (Table 3). Beginning from leaf position 3 or 4 , all the leaves pro-

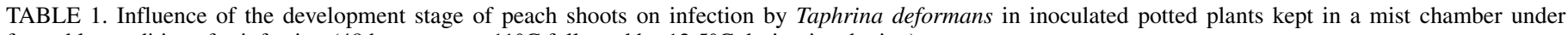
favorable conditions for infection $\left(48 \mathrm{~h}\right.$ wetness at $11^{\circ} \mathrm{C}$ followed by $12.5^{\circ} \mathrm{C}$ during incubation)

\begin{tabular}{|c|c|c|c|c|c|c|}
\hline Visible leaves & $\begin{array}{l}\text { Leaf tuft length } \\
(\mathrm{cm})\end{array}$ & $\begin{array}{l}\text { Internode length } \\
(\mathrm{cm})\end{array}$ & $\begin{array}{c}\text { Expanded } \\
\text { leaves/shoot }\end{array}$ & $\begin{array}{l}\text { No. of growing } \\
\text { shoots }\end{array}$ & $\begin{array}{c}\text { Infected shoots } \\
(\%)\end{array}$ & $\begin{array}{c}\text { Infected } \\
\text { leaves/infected shoo }\end{array}$ \\
\hline 0 & 0.2 & 0 & 0 & 97 & 16 & 1.3 \\
\hline $4-6$ & $1.0-2.5$ & 0 & 0 & 82 & 18 & 1.2 \\
\hline $5-9$ & $2.5-4.5$ & 0 & $0-4$ & 57 & 0 & 0 \\
\hline $6-12$ & $\ldots$ & $0-3$ & $3-7$ & 73 & 0 & 0 \\
\hline $12-16$ & $\ldots$ & $5-10$ & $8-12$ & 30 & 0 & 0 \\
\hline $14-20$ & $\ldots$ & $15-25$ & $12-15$ & 48 & 0 & 0 \\
\hline
\end{tabular}

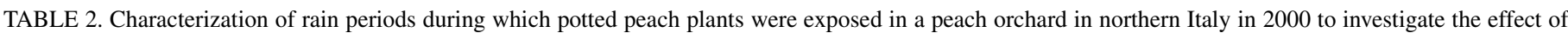
environmental factors on leaf curl development

\begin{tabular}{|c|c|c|c|c|c|c|c|c|c|}
\hline \multirow[b]{2}{*}{ Plant group } & \multirow[b]{2}{*}{ Exposure period } & \multirow[b]{2}{*}{ Rain (mm) } & \multirow[b]{2}{*}{ Wet period $(\mathrm{h})^{\mathrm{a}}$} & \multirow[b]{2}{*}{$\operatorname{Tinf}\left({ }^{\circ} \mathrm{C}\right)^{\mathrm{b}}$} & \multirow[b]{2}{*}{$\operatorname{Tinc}\left({ }^{\circ} \mathrm{C}\right)^{\mathrm{c}}$} & \multicolumn{2}{|c|}{ Potted plants } & \multicolumn{2}{|c|}{ Orchard trees } \\
\hline & & & & & & Disease onset & Infected shoots $(\%)$ & Symptom onset & Infected shoots $(\%)$ \\
\hline I & 1-2 March & 4.0 & 16 & 7.4 & 10.6 & $\ldots$ & $\ldots$ & 25 March & 1 \\
\hline II & $20 \mathrm{March}$ & 2.0 & 9 & 5.7 & 10.8 & $\ldots$ & $\ldots$ & $\ldots$ & $\ldots$ \\
\hline III & 25 March & 3.0 & 9 & 11.3 & 10.9 & $\ldots$ & $\ldots$ & $\ldots$ & $\ldots$ \\
\hline IV & $27 \mathrm{March}$ & 3.0 & 4 & 9.8 & 10.8 & $\ldots$ & $\ldots$ & $\cdots$ & $\ldots$ \\
\hline V & 28-29 March & 13.0 & 24 & 9.7 & 11.3 & $\ldots$ & $\ldots$ & 12 April & 30 \\
\hline VI & 1 April & 7.0 & 14 & 9.3 & 12.2 & $\ldots$ & $\ldots$ & $\ldots$ & $\ldots$ \\
\hline VII & 3-4 April & 13.0 & 41.5 & 9.5 & 13.8 & 19 April & 48 & 19 April & 60 \\
\hline VIII & 6 April & 19.0 & 13 & 9.1 & 14.5 & $\ldots$ & $\ldots$ & $\ldots$ & $\ldots$ \\
\hline IX & 9-11 April & 19.0 & 59 & 8.7 & 16.3 & 26 April & 51 & 26 April & 35 \\
\hline$X$ & 29-30 April & 15.0 & 35 & 15.0 & 18.4 & 20 May & 14 & $\ldots$ & $\ldots$ \\
\hline XI & 6-7 May & 7.5 & 43 & 17.7 & 19.7 & $\ldots$ & $\ldots$ & $\ldots$ & $\ldots$ \\
\hline XII & 11 May & 2.0 & 27 & 19.5 & 20.2 & $\ldots$ & $\ldots$ & $\ldots$ & $\ldots$ \\
\hline
\end{tabular}

${ }^{a}$ Hours of continuous wetness or interrupted for a maximum of $4 \mathrm{~h}$.

b Average air temperature during the wet period.

c Average air temperature during incubation (i.e., between the end of a wet period and symptom onset). 
duced by the shoot tip were infected, with $100 \%$ severity, and symptoms also appeared on internodes. This infection likely occurred on 24 to 25 February (Table 3), when rainfall of $12 \mathrm{~mm}$ triggered a wet period of $35.5 \mathrm{~h}$ with Tinf of $3.2^{\circ} \mathrm{C}$. At this date, $78 \%$ of buds were open, with a green tip $\leq 3 \mathrm{~mm}$. Between 2 and $4 \mathrm{March}, 36 \mathrm{~mm}$ of rainfall, with a wet period of $54 \mathrm{~h}$ and Tinf of $5.9^{\circ} \mathrm{C}$, favored an infection that became visible between 27 and 31 March (Table 3 ). In all, $\approx 9 \%$ of shoots were affected, with very severe symptoms affecting all the leaves beginning with those in position 6 or 7 . Other severe symptoms were observed between 1 and 7 April on $22 \%$ of the shoots, presumably caused by a wet period of $14.5 \mathrm{~h}$ on 9 March (Table 3).

A second group of less severe symptoms appeared in four periods: 18 to 21 April, 25 to 28 April, 30 April to 6 May, and 13 May (Table 3). Leaf curl affected only one to three leaves per shoot, starting from leaf position 7 or 8 , each leaf with $<30$ to $40 \%$ of the leaf blade affected. Infections that presumably caused these symptoms occurred between 27 March and 12 April, with rainfall between 5 and $67 \mathrm{~mm}$, wet periods of 21 to $42 \mathrm{~h}$, and Tinf between 9.7 and $10.8^{\circ} \mathrm{C}$.

Two further infections appeared later, on 5 to 13 and 19 to 26 May (Table 3), with very light symptoms (severity 1 to $15 \%$ ) on one or two leaves in positions between 11 and 15. Conditions favoring these infections probably occurred between 16 April and 4 May, with $6 \mathrm{~mm}$ of rainfall, wet periods of 25 and $16 \mathrm{~h}$, and Tinf of 9.8 and $14.5^{\circ} \mathrm{C}$.

In the considered period, there were another 26 cases with presence of wetness caused by rainfall, dew, or fog that did not result in the appearance of symptoms (Table 3). During these periods, duration of wetness lasted 0.5 to $36 \mathrm{~h}$, with Tinf between 1.4 and $22.5^{\circ} \mathrm{C}$. In only five cases, the wet periods were $\geq 12 \mathrm{~h}$. On 22 and 24 April and on 2 May, wet periods were 14 to $16 \mathrm{~h}$ long and Tinf was low $\left(5.3,6.5\right.$, and $\left.16.2^{\circ} \mathrm{C}\right)$, but rainfall was lower $(0.2 \mathrm{~mm})$ than when similar conditions of wetness and temperature allowed infection to occur (at least $5 \mathrm{~mm}$ of rainfall). On 7 and 20 to 21 May, rainfall was higher (27 and $9 \mathrm{~mm}$, respectively), wetness lasted 14.5 to $36 \mathrm{~h}$, respectively, and Tinf was $\approx 14^{\circ} \mathrm{C}$; nevertheless, disease did not appear. Under the hypothesis that infection had taken place in these two cases, air temperature calculated for the presumed incubation period was higher $\left(18\right.$ to $\left.20^{\circ} \mathrm{C}\right)$ than in the cases with successful infection $\left(10\right.$ to $\left.16^{\circ} \mathrm{C}\right)$.

Disease development in 2002. The first breaking buds were observed on 13 February. On 5 March, all the buds were at green tip and the most advanced shoots had four to six leaves. The phase of rapid shoot development started at the end of March; between late March and the end of May, leaves were produced at a rate of one leaf every 4 days (Fig. 4B). Rainfall occurred soon after bud break, but a long dry period occurred between 24 February and 8 April, with only $3.2 \mathrm{~mm}$ of rain falling over 2 days. In April and May, precipitation was abundant and regularly distributed (Fig. 4B).

Three close periods of leaf curl onset were observed in the first period of host growth between 9 and 31 March (Table 4). A break in the daily increase of disease incidence and a difference between the first leaves showing symptoms made separation between these periods possible. Infected shoots showed severe symptoms, with all leaves above the first infected one being completely curled (severity 100\%). The correspondent infection periods likely occurred on 15 to 16 and 21 February and on 5 March, when rainfall ranged between 3 and $42 \mathrm{~mm}$, length of wetness between 12.5 and $28 \mathrm{~h}$, and Tinf between 6.6 and $9.6^{\circ} \mathrm{C}$.

Further symptoms appeared between 25 April and 3 May and between 11 and 15 May (Table 4). They affected 86 and 3\% of shoots, respectively, each shoot showing one to four affected leaves, starting from positions 8 or 9 , with 3 to $40 \%$ severity. The correspondent infections likely occurred on 8 to 10 April $(37 \mathrm{~mm}$ of total rainfall, $54 \mathrm{~h}$ of wetness at $\left.8^{\circ} \mathrm{C}\right), 11$ to 13 April $(40 \mathrm{~mm}$, $\left.44 \mathrm{~h}, 9.6^{\circ} \mathrm{C}\right)$, and 20 to 21 April $\left(19 \mathrm{~mm}, 24 \mathrm{~h}, 11.4^{\circ} \mathrm{C}\right)$.
The last infection occurred on 8 to 9 May (Table 4), with $39 \mathrm{~mm}$ of rainfall, $26 \mathrm{~h}$ of wetness, and $15.6^{\circ} \mathrm{C}$. These symptoms appeared on few shoots $(<1 \%)$ on one or two top leaves, with a severity of 10 to $20 \%$.

In the period between bud break and the end of May, there were another 26 cases with presence of wetness caused by rainfall, dew, or fog that were not followed by symptom development (Table 4). In these cases, the wet period lasted 0.5 to $40 \mathrm{~h}$, with Tinf between 5.5 and $26.3^{\circ} \mathrm{C}$. In only four cases, wet periods were $\geq 12 \mathrm{~h}$. On 2 to 3 May, 4 May, and 24 May, rainfall was 4 to $6 \mathrm{~mm}$ and the wet periods were 12 to $18.5 \mathrm{~h}$ long, but Tinf was higher $\left(16\right.$ to $17^{\circ} \mathrm{C}$ ) than when similar conditions of rainfall and wetness allowed infection to occur. On 10 to 11 May, $3 \mathrm{~mm}$ of rainfall triggered a wet period of $14 \mathrm{~h}$ at $15.2^{\circ} \mathrm{C}$, but no disease appeared following a presumed incubation of 15 days at $18.8^{\circ} \mathrm{C}$. In contrast, a very light infection occurred on 8 to 9 May, with a longer wet period $(26 \mathrm{~h})$ at $15.6^{\circ} \mathrm{C}$ and Tinc of $18.9^{\circ} \mathrm{C}$.

Weather conditions favoring infection in the orchard. Based on the previously described observations made in the orchard dur-

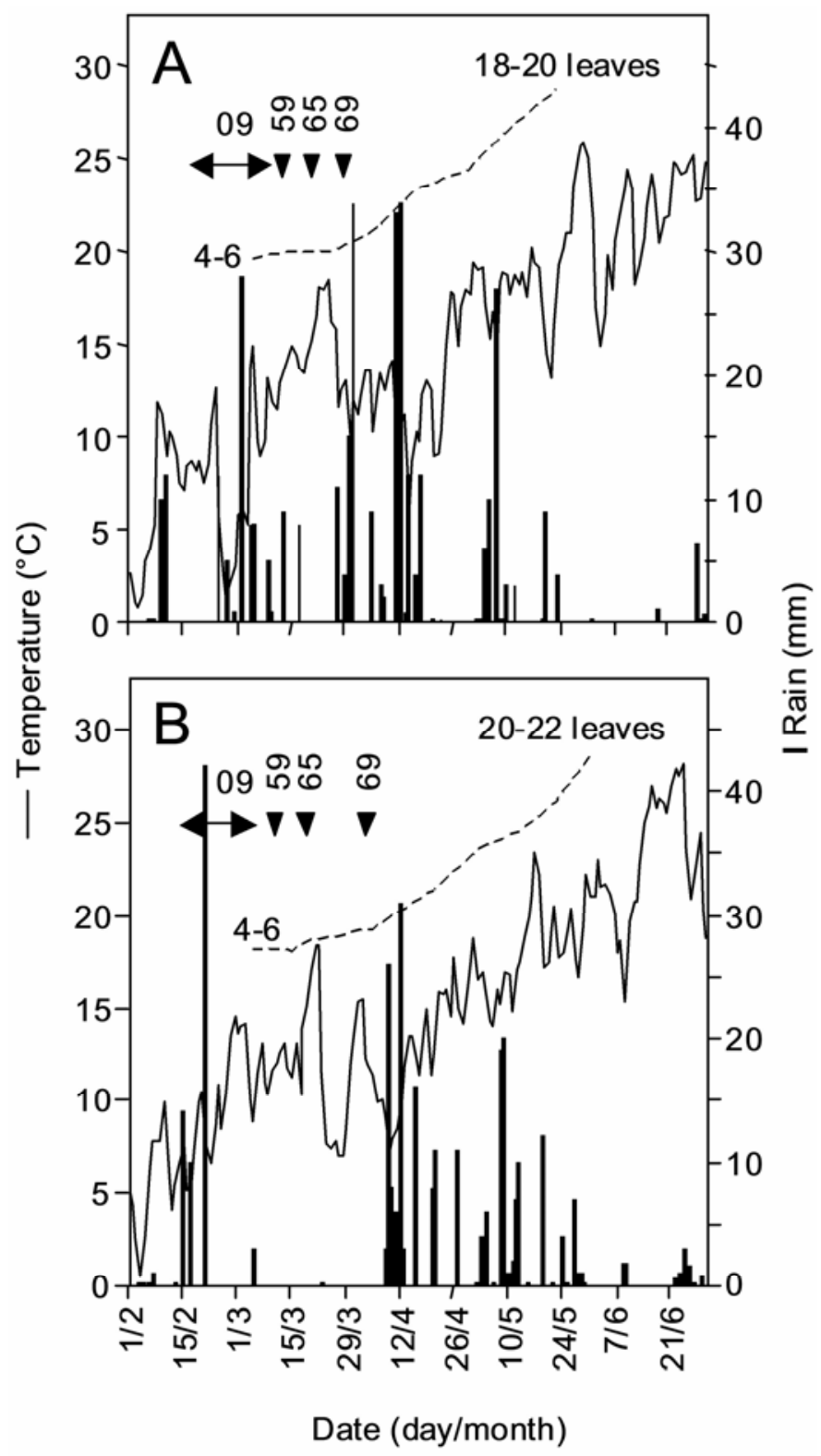

Fig. 4. Daily air temperature and rainfall in the peach orchard located at Zattaglia (northern Italy) in A, 2001 and B, 2002. Arrows identify the growth stages according to the $\mathrm{BBCH}$ scale (3), whereas the dotted line indicates the dynamics of leaf production on peach shoots. 
ing 2001 and 2002, all days with at least 30 min of wetness occurring between the beginning of bud break and the end of May (Tables 3 and 4) were split into two groups: (i) days with infection and (ii) days without infection.

In the no-infection group, average rainfall was $4 \mathrm{~mm}$, whereas in the infection group, average rainfall was $24 \mathrm{~mm}$ (minimum $3 \mathrm{~mm}$ ) (Table 5). The two distributions were significantly different at $P=0.0002$, but there was a wide interval of rainfall values where the two groups overlapped (Fig. 5A). When there was no infection, the wet period was $6.6 \mathrm{~h}$ long, whereas it was $30.4 \mathrm{~h}$ long when infection occurred (Table 5). Also, in this case, the two distributions were significantly different at $P=0.0001$, but the range of wetness durations where the two groups overlapped was narrow; this range included the fourth quartile of the group with no infection and the first quartile of the group with infection (Fig. 5B). Tinf was $13.5^{\circ} \mathrm{C}$ when infection did not occur, but it was $9.6^{\circ} \mathrm{C}$ in cases with infection (Table 5). Data distributions for the two groups overlapped for all the temperatures lower than $15.6^{\circ} \mathrm{C}$ (Fig. 5C). Tinc was $13.5^{\circ} \mathrm{C}$, with a maximum of $18.9^{\circ} \mathrm{C}$ (Table 5).

Based on these data, at least $3 \mathrm{~mm}$ of rainfall with minimum $12.5 \mathrm{~h}$ of wetness at a temperature $<16^{\circ} \mathrm{C}$ and an incubation temperature $<19^{\circ} \mathrm{C}$ were necessary for infection to occur. When the cases of Tables 3 and 4 were grouped in the two groups (no infec- tion and infection) according to all the above-mentioned thresholds, they correctly classified 66 of 68 cases (97\%) (Table 6). In the remaining two cases (3\%), infection was overestimated. This occurred on 7 May 2001 and on 10 to 11 May 2002; in these cases, the estimated Tinc was 18.4 and $18.8^{\circ} \mathrm{C}$, respectively, which was near the threshold $\left(<19^{\circ} \mathrm{C}\right)$.

When the threshold values were applied to data from the experiment done in 2000 (Table 1), the five infections that occurred on either potted plants or orchard trees were correctly estimated, as well as five of the seven periods with no infection (Table 6). In two cases, infection was overestimated. This occurred for plants exposed on 1 and 6 April: wet periods of 13 to $14 \mathrm{~h}$ in these cases were near the threshold $(\geq 12.5 \mathrm{~h})$.

\section{DISCUSSION}

In the present work, weather conditions allowing $T$. deformans infection to occur were investigated under both controlled-environment and orchard conditions. In the former experiments, infection was obtained by maintaining naturally inoculated potted plants under favourable environmental conditions; whereas, in the latter experiments, infection periods were inferred from symptom appearance based on temperature-incubation relationships found in controlled-environment conditions. The general agreement be-

TABLE 3. Characterization of wet periods recorded in a peach orchard in northern Italy in 2001 and relationships between wet periods and leaf curl development

\begin{tabular}{|c|c|c|c|c|c|c|c|}
\hline Month, day & Rain (mm) & Wet period $(\mathrm{h})^{\mathrm{a}}$ & $\operatorname{Tinf}\left({ }^{\circ} \mathrm{C}\right)^{\mathrm{b}}$ & $\operatorname{Tinc}\left({ }^{\circ} \mathrm{C}\right)^{\mathrm{c}}$ & Infection period $^{\mathrm{d}}$ & Symptom onset & Infected shoots $(\%)$ \\
\hline \multicolumn{8}{|l|}{ February } \\
\hline $24-25$ & 24 & 35.5 & 3.2 & 10.1 & I & 19-27 March & 31.0 \\
\hline 26 & 5 & 5 & 1.4 & $\ldots$ & $\ldots$ & $\ldots$ & $\ldots$ \\
\hline 28 & 1 & 6 & 4.8 & $\ldots$ & $\ldots$ & $\ldots$ & $\ldots$ \\
\hline \multicolumn{8}{|l|}{ March } \\
\hline $2-4$ & 36 & 54 & 5.9 & 14.1 & II & 27-31 March & 9.4 \\
\hline 5 & 8 & 9.5 & 14.8 & $\ldots$ & $\ldots$ & $\ldots$ & $\ldots$ \\
\hline 6 & Dew & 6 & 9.5 & $\ldots$ & $\ldots$ & $\ldots$ & $\ldots$ \\
\hline 9 & 5 & 14.5 & 11.5 & 14.1 & III & 1-7 April & 22.2 \\
\hline 10 & 1 & 4.5 & 13.1 & $\ldots$ & $\ldots$ & $\ldots$ & $\ldots$ \\
\hline 12 & Fog & 1 & 11.5 & $\ldots$ & $\ldots$ & $\ldots$ & $\ldots$ \\
\hline 13 & 9 & 4 & 12.9 & $\ldots$ & $\ldots$ & $\ldots$ & $\ldots$ \\
\hline 17 & 8 & 4 & 14 & $\ldots$ & $\ldots$ & $\ldots$ & $\ldots$ \\
\hline 25 & Dew & 7 & 10.7 & $\ldots$ & $\ldots$ & $\ldots$ & $\ldots$ \\
\hline 27 & 11 & 21 & 9.7 & 11.5 & IV & 18-21 April & 7.8 \\
\hline 28 & 0.2 & 1 & 14.2 & $\ldots$ & $\ldots$ & $\ldots$ & $\ldots$ \\
\hline 29 & 4 & 2 & 11.8 & $\ldots$ & $\ldots$ & $\ldots$ & $\ldots$ \\
\hline $30-31$ & 49 & 42 & 10.5 & 11.6 & $\mathrm{~V}$ & 25-28 April & 5.2 \\
\hline \multicolumn{8}{|l|}{ April } \\
\hline 5 & 9 & 5 & 10.6 & $\ldots$ & $\ldots$ & $\ldots$ & $\ldots$ \\
\hline $7-8$ & 5 & 38 & 10.8 & 12.7 & VI & 30 April-6 May & 36.0 \\
\hline $11-12$ & 67 & 36 & 9.9 & 13.9 & VII & 13 May & 1.0 \\
\hline 14 & 12 & 9.5 & 5.6 & $\ldots$ & $\ldots$ & $\ldots$ & $\ldots$ \\
\hline $16-17$ & 6 & 25 & 9.8 & 15.3 & VIII & 5-13 May & 4.7 \\
\hline 22 & 0.2 & 14 & 5.3 & $\ldots$ & $\ldots$ & $\ldots$ & $\ldots$ \\
\hline 24 & 0.2 & 15 & 6.5 & $\ldots$ & $\ldots$ & $\ldots$ & $\ldots$ \\
\hline \multicolumn{8}{|l|}{ May } \\
\hline 2 & 0.2 & 17 & 16.2 & $\ldots$ & $\ldots$ & $\ldots$ & $\ldots$ \\
\hline 3 & 0.2 & 2 & 17.6 & $\ldots$ & $\ldots$ & $\ldots$ & $\ldots$ \\
\hline 4 & 6 & 16 & 14.5 & 16 & IX & 19-26 May & 7.6 \\
\hline 5 & 10 & 11 & 15.5 & $\ldots$ & $\ldots$ & $\ldots$ & $\ldots$ \\
\hline 7 & 27 & 14.5 & 14.1 & $\ldots$ & $\ldots$ & $\ldots$ & $\ldots$ \\
\hline 8 & 0.2 & 2.5 & 14.3 & $\ldots$ & $\ldots$ & $\ldots$ & $\ldots$ \\
\hline 10 & 3 & 0.5 & 22.5 & $\ldots$ & $\ldots$ & $\ldots$ & $\ldots$ \\
\hline 12 & 3 & 3.5 & 13.7 & $\ldots$ & $\ldots$ & $\ldots$ & $\ldots$ \\
\hline 18 & Fog & 5.5 & 15.2 & $\ldots$ & $\ldots$ & $\ldots$ & $\ldots$ \\
\hline 19 & 0.4 & 3 & 11.6 & $\ldots$ & $\ldots$ & $\ldots$ & $\ldots$ \\
\hline $20-21$ & Dew 9 & 36 & 13.7 & $\ldots$ & $\ldots$ & $\ldots$ & $\ldots$ \\
\hline 23 & 4 & 3 & 21.1 & $\ldots$ & $\ldots$ & $\ldots$ & $\ldots$ \\
\hline
\end{tabular}

${ }^{a}$ Hours of continuous wetness or interrupted for a maximum of $4 \mathrm{~h}$.

b Average air temperature during the wet period.

${ }^{c}$ Average air temperature during incubation (i.e., between the end of a wet period and symptom onset).

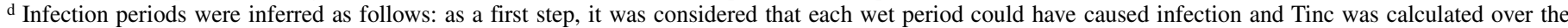
time interval between the beginning of the wet period and the day when the incubation period should have ended, based on the equation in Figure 3 . When disease symptoms actually appeared, the corresponding wet period was considered a true infection period. 
tween these two approaches, as well as the reproducibility of the data obtained in controlled conditions, makes the results robust.

For infection to occur, wetness was more important than rainfall. Under orchard conditions, minimum rainfall causing infection was $3 \mathrm{~mm}$, with a wet period of at least $12.5 \mathrm{~h}$; higher amounts of rainfall did not cause infection when the wet period they triggered was shorter. In the absence of rainfall, wet periods initiated by dew or fog were not favorable for infection because they were always shorter than $11 \mathrm{~h}$ in the orchard studied. Experiments made in controlled-environment conditions confirmed that wet periods shorter than $12 \mathrm{~h}$ did not allow infection and showed that disease incidence increased with the duration of wetness, reaching the highest value with a wet period $\geq 48 \mathrm{~h}$.

TABLE 4. Characterization of wet periods recorded in a peach orchard in northern Italy in 2002 and relationships between wet periods and leaf curl development

\begin{tabular}{|c|c|c|c|c|c|c|c|}
\hline Month, day & Rain (mm) & Wet period $(h)^{\mathrm{a}}$ & $\operatorname{Tinf}\left({ }^{\circ} \mathrm{C}\right)^{b}$ & Tinc $\left({ }^{\circ} \mathrm{C}\right)^{\mathrm{c}}$ & Infection period $^{\mathrm{d}}$ & Symptom onset & Infected shoots $(\%)$ \\
\hline \multicolumn{8}{|l|}{ February } \\
\hline $15-16$ & 14 & 28 & 6.9 & 10.4 & I & 9-12 March & 1.0 \\
\hline 17 & 10 & 3.5 & 5.5 & $\ldots$ & $\ldots$ & $\ldots$ & $\ldots$ \\
\hline 21 & 42 & 15.5 & 6.6 & 11.4 & II & 13-21 March & 4.0 \\
\hline \multicolumn{8}{|l|}{ March } \\
\hline 5 & 3 & 12.5 & 9.6 & 13.3 & III & 23-31 March & 2.8 \\
\hline 15 & Dew & 3 & 9.7 & $\ldots$ & $\ldots$ & $\ldots$ & $\ldots$ \\
\hline 23 & 0.2 & 1.5 & 10.7 & $\ldots$ & $\ldots$ & $\ldots$ & $\ldots$ \\
\hline \multicolumn{8}{|l|}{ April } \\
\hline 3 & Dew & 1 & 5.9 & $\ldots$ & $\ldots$ & $\ldots$ & $\ldots$ \\
\hline 4 & Dew & 10.5 & 8.9 & $\ldots$ & $\ldots$ & $\ldots$ & $\ldots$ \\
\hline 6 & Fog & 3.5 & 10.9 & $\ldots$ & $\ldots$ & $\ldots$ & $\ldots$ \\
\hline $8-10$ & 37 & 54 & 8 & 12.8 & IV & 25 April -3 May & 86.2 \\
\hline $11-13$ & 40 & 44 & 9.6 & 12.8 & V & 25 April -3 May & 86.2 \\
\hline 16 & 16 & 11.5 & 11.1 & $\ldots$ & $\ldots$ & $\ldots$ & $\ldots$ \\
\hline 17 & Dew & 10 & 9.7 & $\ldots$ & $\ldots$ & $\ldots$ & $\ldots$ \\
\hline $20-21$ & 19 & 24 & 11.4 & 16.2 & VI & 11-15 May & 2.9 \\
\hline 23 & Dew & 2 & 11.5 & $\ldots$ & $\ldots$ & $\ldots$ & $\ldots$ \\
\hline 27 & 11 & 4 & 14.8 & $\ldots$ & $\ldots$ & $\ldots$ & $\ldots$ \\
\hline \multicolumn{8}{|l|}{ May } \\
\hline $2-3$ & 4.2 & 18.5 & 16 & $\ldots$ & $\ldots$ & $\ldots$ & $\ldots$ \\
\hline 4 & 6 & 16.5 & 16.8 & $\ldots$ & $\ldots$ & $\ldots$ & $\ldots$ \\
\hline 5 & Dew & 8 & 12.3 & $\ldots$ & $\ldots$ & $\ldots$ & $\ldots$ \\
\hline 6 & 0.2 & 2 & 13.1 & $\ldots$ & $\ldots$ & $\ldots$ & $\ldots$ \\
\hline $8-9$ & 39 & 26 & 15.6 & 18.9 & VII & 23 May & $<1$ \\
\hline $10-11$ & 3 & 14 & 15.2 & $\ldots$ & $\ldots$ & $\ldots$ & $\ldots$ \\
\hline 12 & 7 & 3 & 15.8 & $\ldots$ & $\ldots$ & $\ldots$ & $\ldots$ \\
\hline 13 & 10 & 1.5 & 18.9 & $\ldots$ & $\ldots$ & $\ldots$ & $\ldots$ \\
\hline 15 & 0.2 & 1 & 22.4 & $\ldots$ & $\ldots$ & $\ldots$ & $\ldots$ \\
\hline 16 & Fog & 1.5 & 16.5 & $\ldots$ & $\ldots$ & $\ldots$ & $\ldots$ \\
\hline 19 & 12 & 5.5 & 14.9 & $\ldots$ & $\ldots$ & $\ldots$ & $\ldots$ \\
\hline 21 & 0.2 & 1 & 22.9 & $\ldots$ & $\ldots$ & $\ldots$ & $\ldots$ \\
\hline 24 & 4 & 12 & 17 & $\ldots$ & $\ldots$ & $\ldots$ & $\ldots$ \\
\hline 25 & 0.2 & 4 & 18.9 & $\ldots$ & $\ldots$ & $\ldots$ & $\ldots$ \\
\hline 27 & 7 & 3.5 & 15.9 & $\ldots$ & $\ldots$ & $\ldots$ & $\ldots$ \\
\hline $28-29$ & 2 & 9.5 & 16.4 & $\ldots$ & $\ldots$ & $\ldots$ & $\ldots$ \\
\hline 30 & 0.2 & 0.5 & 26.3 & $\ldots$ & $\ldots$ & $\ldots$ & $\ldots$ \\
\hline
\end{tabular}

a Hours of continuous wetness or interrupted for a maximum of $4 \mathrm{~h}$.

b Average air temperature during the wet period.

c Average air temperature during incubation (i.e., between the end of a wet period and symptom onset.

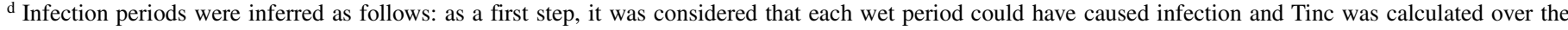
time interval between the beginning of the wet period and the day when the incubation period should have ended, based on the equation in Figure 3 . When disease symptoms actually appeared, the corresponding wet period was considered a true infection period.

TABLE 5. Characterization of infection periods of Taphrina deformans on peach shoots in an orchard at Zattaglia (northern Italy) in 2001 and 2002

\begin{tabular}{|c|c|c|c|c|c|c|}
\hline Variables & Infection $^{\mathrm{a}}$ & Mean & $P^{\mathrm{b}}$ & Standard deviation & Minimum & Maximum \\
\hline \multirow[t]{2}{*}{ Rain (mm) } & No & 4.0 & 0.000 & 0.75 & 0 & 27 \\
\hline & Yes & 24.4 & $\ldots$ & 4.93 & 3 & 67 \\
\hline \multirow[t]{2}{*}{ Wet period $(h)^{c}$} & No & 6.6 & 0.000 & 0.89 & 0.5 & 36.0 \\
\hline & Yes & 30.4 & $\ldots$ & 3.38 & 12.5 & 54.0 \\
\hline \multirow[t]{2}{*}{$\operatorname{Tinf}\left({ }^{\circ} \mathrm{C}\right)^{\mathrm{d}}$} & No & 13.5 & 0.005 & 0.69 & 1.4 & 26.3 \\
\hline & Yes & 9.6 & $\ldots$ & 0.77 & 3.2 & 15.6 \\
\hline \multirow[t]{2}{*}{$\operatorname{Tinc}\left({ }^{\circ} \mathrm{C}\right)^{\mathrm{e}}$} & No & $\ldots$ & $\ldots$ & $\ldots$ & $\ldots$ & $\ldots$ \\
\hline & Yes & 13.5 & $\ldots$ & 0.62 & 10.1 & 18.9 \\
\hline
\end{tabular}

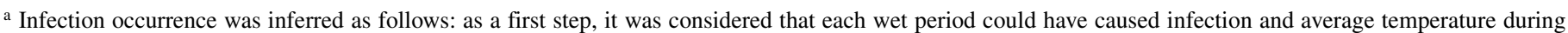
incubation (Tinc) was calculated over the time interval between the beginning of the wet period and the day when the incubation period should have ended, based on the equation in Figure 3. When disease symptoms actually appeared, the corresponding wet period was considered a true infection period. No, $n=52$ cases; Yes, $n=16$ cases.

b Probability level for the $t$ test for difference between means.

${ }^{c}$ Hours of continuous wetness or interrupted for a maximum of $4 \mathrm{~h}$.

d Average air temperature during the wet period.

e Average air temperature during incubation (i.e., between the end of a wet period and symptom onset). 
The predominant role of surface wetness duration over rainfall is a new finding in $T$. deformans epidemiology, because previous works assigned a key effect to rainfall and omitted the role of wetness. Mix (14) observed disease symptoms 2 weeks after the first rainfall that occurred after bud break; because there was a relationship between the duration of rainfall and incidence of the disease, rain duration was considered the limiting factor for infection. Safran and Levy (22) observed the appearance of leaf curl 3 to 6 weeks after a rain event of at least $20 \mathrm{~mm}$. They considered that spores stick strongly to plant surfaces (16), and that a weak rain, $<10 \mathrm{~mm}$ per day, does not allow inoculation of young leaves to occur. Therefore, they considered the intensity of rain as the key factor for infection. The determinant role of rainfall also was demonstrated by the absence of leaf curl in peach plants protected from rainfall by covers $(4,6,9,18)$.

Because the above-mentioned authors did not measure presence and duration of wetness, there is not a true contradiction with the data collected in the present work. Mix (15) considered rain duration as a limiting factor for infection: rainfall can initiate wet periods and favor prolonged wetting when the rain events are of long duration. Safran and Levy (22) paid more attention to rain quantity: a heavy rainfall can ensure a long wet period and, moreover,

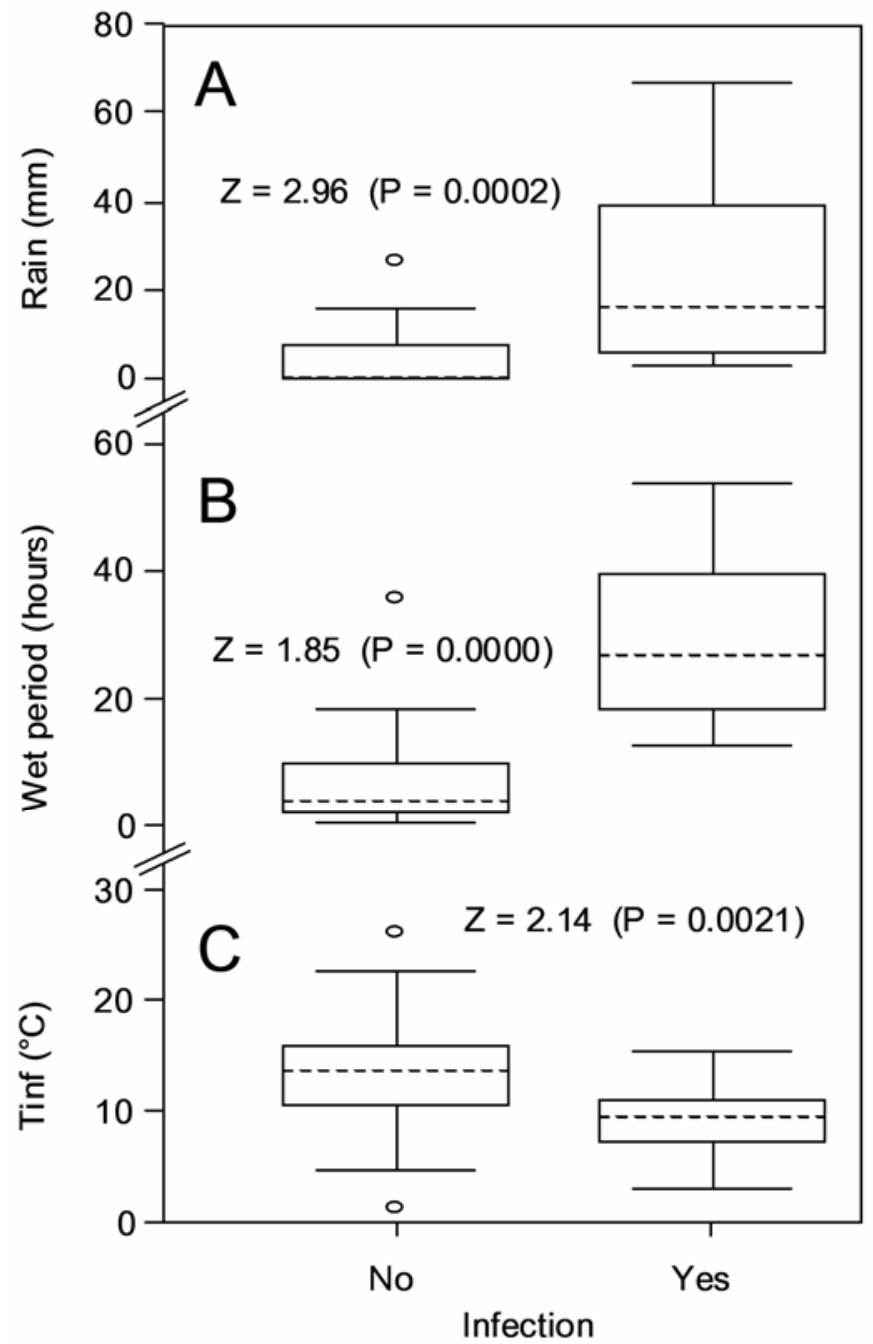

Fig. 5. Box and whisker plots showing distribution of $\mathbf{A}$, rainfall, $\mathbf{B}$, duration of wet periods, and $\mathbf{C}$, temperature during wetness (Tinf) for the cases shown in Tables 3 and 4, separated into two groups: with or without leaf curl infection. The $Z$ values were calculated using the Kolmogorov-Smirnov Test under the null hypothesis that the two groups belong to the same distribution. Boxes include $50 \%$ of data, dotted lines indicate the median, whiskers extend to minimum and maximum values, and circles denote outliers. can efficiently disperse spores to the penetration sites at shoot tips by means of splashed droplets. Spore dispersal was not investigated in the present work, but some information can be presumed from the experimental data. The potted peach plants exposed in affected peach orchards during the growing season and then kept in mist chambers under environmental conditions favoring infection and incubation always showed severe disease symptoms. Therefore, viable spores always reached the infection sites for the considered orchard conditions. Disease symptoms on these potted plants appeared only when shoots had no more than four to six visible leaves (leaf tuft shorter than $2.5 \mathrm{~cm}$ ) at the time the plants were in the mist chamber. In contrast, when the plants had more developed shoots, infection did not occur. Because the developing shoots were susceptible to infection under natural conditions in the orchard, where favorable conditions of wetting and temperature were preceded by rainfall, the lack of infection in such potted plants must be assigned to the absence of spores at the infection sites in the shoot tip. Therefore, rainfall is not necessary for infection when shoots have up to four to six visible leaves, because the inoculum is already present in the infection sites. This finding is in agreement with Fitzpatrick $(7,8)$ and Mix $(16)$, who obtained infection on plants wetted for long periods in greenhouses, but not exposed to rainfall, only when they artificially inoculated spores within the opening buds. Otherwise, rain splash becomes necessary for infection when the shoot is more developed, because it transports the inoculum to the shoot tip.

The effect of temperature on infection was investigated separately for the wet (infection) period and the incubation period. Under orchard conditions, infection occurred only when average air temperature was $<16^{\circ} \mathrm{C}$ during the wet period and $<19^{\circ} \mathrm{C}$ during incubation. These observations were confirmed by experiments carried out in controlled conditions. Disease incidence was highest when temperatures during a 48-h-long wet period ranged between 5 and $8^{\circ} \mathrm{C}$; however, in the orchard, disease occurred also at $\approx 3^{\circ} \mathrm{C}$. Infection decreased to approximately zero at $16^{\circ} \mathrm{C}$ or higher temperatures. Incubation temperature did not affect disease incidence between 8 and $15^{\circ} \mathrm{C}$, but it reduced disease between 16 and $19^{\circ} \mathrm{C}$ and it did not allow disease to appear at $20^{\circ} \mathrm{C}$ or higher temperatures.

A comparison between these results and previous knowledge is difficult, because similar experiments have not been reported in the past. Pscheidt (19) stated that periods of cool weather during early bud development favor leaf curl, and that the optimum temperature for fungal growth is at $20^{\circ} \mathrm{C}$, the minimum at $8.9^{\circ} \mathrm{C}$, and the maximum between 26 and $30^{\circ} \mathrm{C}$. Here, there is an apparent discrepancy because temperatures during early bud development usually are cooler than temperatures favoring fungal growth. Observations made in natural conditions confirm this discrepancy, with infection occurring when maximum air temperature did not

TABLE 6. Comparison between actual and predicted leaf curl infections at Zattaglia (northern Italy) ${ }^{\mathrm{a}}$

\begin{tabular}{lccllll}
\hline & \multicolumn{2}{c}{ Predicted $2001-02^{\mathrm{b}}$} & & \multicolumn{2}{c}{ Predicted 2000 } \\
\cline { 2 - 3 } \cline { 5 - 6 } Actual & \multicolumn{2}{c}{ No } & Yes & & No & Yes \\
\hline No & $50(73.5 \%)$ & $2(2.9 \%)$ & & $5(41.7 \%)$ & $2(16.6 \%)$ \\
Yes & 0 & $16(23.5 \%)$ & & 0 & $5(41.7 \%)$ \\
$\chi^{2}$ & & $58.1(P=0.000)$ & & \multicolumn{2}{c}{$6.1(P=0.013)$} \\
\hline
\end{tabular}

${ }^{a}$ Infection occurrence was inferred as follows: as a first step, it was considered that each wet period could have caused infection and average temperature during incubation was calculated over the time interval between the beginning of the wet period and the day when the incubation period should have ended, based on the equation in Figure 3. When disease symptoms actually appeared, the corresponding wet period was considered a true infection period. Predicted infection periods were based on the following criteria: $\geq 3 \mathrm{~mm}$ rain, $\geq 12.5 \mathrm{~h}$ of leaf wetness at a temperature $<16^{\circ} \mathrm{C}$, followed by an average incubation period temperature $<19^{\circ} \mathrm{C}$.

${ }^{\mathrm{b}}$ In orchard trees.

c In either potted plants or orchard trees. 
exceed 10 to $20^{\circ} \mathrm{C}(1,12,24)$. The cardinal temperatures indicated by Pscheidt (19) fit better with the results obtained in vitro with budding blastospores $(2,10,12,14,23)$. Thus, the fungus appears to have different temperature requirements for infection and for spore budding.

Quantitative relationships between temperature and infection have been defined in this work for the first time. Differences also were found between temperatures during the wet period and temperatures during incubation. Fitzpatrick (8) observed that plants which had been inoculated in moist chambers at 10 to $18^{\circ} \mathrm{C}$ for $48 \mathrm{~h}$ did not show typical leaf curl symptoms when they were incubated at $21^{\circ} \mathrm{C}$, but severe symptoms appeared when the plants were incubated at 10 to $16^{\circ} \mathrm{C}$. Microscopic observations showed that fungal hyphae grew inside the leaf tissue of all the inoculated plants. Therefore, Fitzpatrick (8) argued that leaves incubated at higher temperatures outgrew infection because of factors operating after penetration has taken place. The leaf tissues are susceptible to infection only before differentiation (7). Because leaves grown on plants incubated at higher temperatures developed rapidly, they quickly overcame the susceptible stage and, thus, became resistant to any further spread of the fungus; as a consequence, infection was unable to develop beyond the initial stage (8). According to Fitzpatrick, the limiting effect of high temperatures during incubation is due mainly to the speed of leaf development. This finding also can explain the dynamics of leaf curl symptoms over the season. At the start of the season (mid-February to end of March), the shoots developed slowly. At the end of bud break, the shoots had four to six visible leaves which formed a tuft of $\approx 1$ to $2.5 \mathrm{~cm}$ in length; no more leaves appeared until petal fall. During this period, temperatures usually were favorable for infection by $T$. deformans and all the observed infections produced severe symptoms. All leaves of an infected shoot were affected, and these leaves were completely curled. Frequently, the shoot apex also was infected so that all the leaves it produced during the shoot extension were affected, and internodes became thickened and distorted. After petal fall, the shoot developed rapidly and both leaf emergence and blade development were faster. In April, temperatures were still favorable for infection but the disease affected only two to four leaves per shoot, with a severity ranging between 3 and $40 \%$ of the leaf blade. In May, temperatures were higher and they dropped below the limit for infection only occasionally; when this occurred, only one to two leaves per shoot showed disease symptoms, with a maximum $15 \%$ of leaf blade affected.

In conclusion, findings from the present work help to provide a better definition of the role of environmental conditions and host growth on infection by $T$. deformans. These results will be used to improve the model elaborated by Safran and Levy (22) and modified by Giosuè et al. (11) in order to make its predictions more accurate and robust.

\section{ACKNOWLEDGMENTS}

This work is part of research promoted and supported by the EmiliaRomagna Region (Italy) by means of the co-ordination of the Centro Ricreche Produzioni Vegetali (CRPV).

\section{LITERATURE CITED}

1. Agarwala, R. K. 1966. Effect of temperature and humidity variation on the development of peach leaf curl in mid hills and its control. Indian Phytopathol. 19:308-309.

2. Anderson, H. W. 1956. Disease of Fruit Crops. McGraw-Hill, New York.

3. Anonymous. 1997. Compendium of Growth Stage Identification Keys for Mono- and Dicotyledonous Plants. Extended BBCH scale, 2nd ed. BBA, BSA, IGZ, IVA, AgrEVO, BASF, Bayer, and Novartis, Basel, Switzerland.

4. Bussard, L., and Duval, G. 1907. Arboriculture Fruitiere. Paris.

5. Clewer, A. G., and Scarisbrick, D. H. 2001. Practical Statistics and Experimental Design for Plant and Crop Science. John Wiley, Chichester, UK.

6. Cook, R. T. A., and Baker, H. 1982. Peach leaf curl. The Garden J. R. Bot. Hortic. Soc. 107:449-453.

7. Fitzpatrick, R. E. 1934. The life history and parasitism of Taphrina deformans. Sci. Agric. 14:305-326.

8. Fitzpatrick, R. E. 1935. Further studies on the parasitism of Taphrina deformans. Sci. Agric. 15:341-344.

9. Gandolfi, C. 1915. Alcune osservazioni sull'Exoascus del pesco. Coltivatore $14: 435-437$.

10. Ghillini, C. A. 1952. I parassiti vegetali delle piante: Tafrinacee italiane. Edizioni Agricole, Bologna.

11. Giosuè, S., Spada, G., Rossi, V., Carli, G., and Ponti, I. 2000. Forecasting infections of the leaf curl disease on peaches caused by Taphrina deformans. Eur. J. Plant Pathol. 106:563-571.

12. Lorenz, D. H. 1976. Untersuchungen über das Pathogenitätsverhalten von Taphrina deformans (Berk.) Tul. Phytopathol. Z. 85:333-344.

13. Manaresi, A. 1915. Intorno alla biologia dell'Exoascus deformans (Berk.) Fuck. Riv. Patol. Veg. 7:193-200.

14. Mix, A. J. 1924. Biological and cultural studies of Exoascus deformans. Phytopathology 14:217-233.

15. Mix, A. J. 1925. The weather and peach leaf curl in eastern Kansas in 1924. Phytopathology 15:244-245.

16. Mix, A. J. 1935. The life history of Taphrina deformans. Phytopathology 25:41-66.

17. Molnar, J. 1967. Effect of weather conditions on the development and spread of peach leaf curl (T. deformans). Ochrana Rostlin 3:129-134.

18. Mundy, C. W. A. 1974. Peach leaf curl. The Garden J. R. Bot. Hortic. Soc. 99:460-461.

19. Pscheidt, J. W. 1995. Leaf curl. Page 22 in: Compendium of Stone Fruit Diseases. J. M. Ogawa, E. I. Zehr, G. W. Bird, D. F. Ritchie, K. Uriu, and J. K. Uyemoto, eds. The American Phytopathological Society, St. Paul, MN.

20. Quinn, G. P., and Keough, M. J. 2002. Experimental Design and Data Analysis for Biologists. Cambridge University Press, Cambridge.

21. Rossi, V., Bolognesi, M., Giosuè, S., Mazzini, F., Ponti, I., and Spada, G. 2005. Biologia ed epidemiologia dell'agente della bolla del pesco. Inf. Agrario 10:59-67.

22. Safran, E., and Levy, Y. 1995. Essai de conception d'un modèle de prévision contre la cloque du pêcher. Agronomie 15:49-57.

23. Schneider, A., and René, J. 1969. Influence des conditions physiques et nutritives sur le développement de Taphrina deformans en culture in vitro. C. R. Acad. Sci. Paris Sér. D 268:44-47.

24. Westwood, M. N. 1993. Temperate-Zone Pomology: Physiology and Culture. Timber Press, Portland, OR. 